NBER WORKING PAPER SERIES

\title{
MONOPOLY-CREATING BANK CONSOLIDATION? THE MERGER OF FLEET AND BANKBOSTON
}

\author{
Charles W. Calomiris \\ Thanavut Pornrojnangkool \\ Working Paper 11351 \\ http://www.nber.org/papers/w11351
}
NATIONAL BUREAU OF ECONOMIC RESEARCH
1050 Massachusetts Avenue
Cambridge, MA 02138
May 2005

We thank seminar participants at Columbia Business School, the Federal Deposit Insurance Corporation, and the City University of New York for helpful comments. All errors are our own. The views expressed herein are those of the author(s) and do not necessarily reflect the views of the National Bureau of Economic Research.

(C2005 by Charles W. Calomiris and Thanavut Pornrojnangkool. All rights reserved. Short sections of text, not to exceed two paragraphs, may be quoted without explicit permission provided that full credit, including (C) notice, is given to the source. 
Monopoly-Creating Bank Consolidation? The Merger of Fleet and BankBoston

Charles W. Calomiris and Thanavut Pornrojnangkool

NBER Working Paper No. 11351

May 2005

JEL No. G21, L13, D43, L41

\begin{abstract}
The merger of Fleet and BankBoston in September 1999 resulted in a regional New England lending market in which only one large, universal bank remained. We explore the extent to which that merger resulted in monopoly rents for the combined entity in some niches within the regional loan market. For small- and medium-sized middle-market borrowers, prior to the merger, Fleet and BankBoston charged unusually low loan interest rates, reflecting their ability to realize economies of scope and scale. After the merger, those cost savings were no longer passed on to medium-sized middle-market borrowers, which resulted in an increase in the average interest rate credit spreads to those borrowers of roughly one percent. Small-sized middle-market borrowers (which continued to enjoy the advantage of loan market competition from remaining small banks) maintained their low spreads. Our results suggest that it may be desirable for regulators to consider the concentration in lending markets in addition to deposit markets when evaluating mergers and structuring appropriate divestiture requirements.

Charles W. Calomiris

Graduate School of Business

Columbia University

3022 Broadway Street, Uris Hall

New York, NY 10027

and NBER

cc374@columbia.edu
\end{abstract}

Thanavut Pornrojnangkool

The World Bank

1818 H Street, NW

Washington, DC 20433

bobbytp@aol.com 


\section{Introduction}

Historically, the structure of the U.S. banking industry was highly fragmented. Initially, Supreme Court rulings, restrictions on national banks imposed by the Office of the Comptroller of the Currency, and state laws and regulations governing state chartered banks limited branching. The Bank Holding Company Act of 1956 and its amendments effectively prohibited interstate banking. During the 1980s, most states entered into selective interstate banking agreements that gradually allowed interstate banking on a limited basis. In 1994, legislation effectively eliminated interstate banking restrictions. As a result of these changes, the U.S. banking system has witnessed an accelerated pace of consolidation within and across state borders over the past quarter century.

Proponents of branching and consolidation argued that the removal of such restrictions would promote competition and reduce market power stemming from barriers to entry (e.g. Flannery 1984, Evanoff and Fortier 1988). Consolidated banks also can operate more efficiently through their ability to achieve scale economies associated with better portfolio diversification, scale related economies of scope in product delivery, and lower costs (e.g. Calomiris 2000, Calomiris and Karceski 2000). For the banking system as a whole, an increase in interstate mergers and acquisitions improves average bank performance through better "bank manager discipline" and "survival of the fitness" effects (Jayaratne and Strahan 1996, Hubbard and Palia 1995).

On the other hand, opponents of consolidation have been concerned about an increase in market concentration in some banking markets as a result of mergers. On the deposit side, the potential problem of market power seems to be of little concern, since regulators act to ensure continuing post-market competition in the deposit market, and 
because all banks (large and small) can effectively compete for customer deposits. The Bank Holding Company Act requires that the Federal Reserve Board consider the competitive effects of any merger proposal before granting merger and acquisition approval. As an operational procedure, the Fed applies the Department of Justice Merger Guidelines to measure how such a merger will affect the degree of competition in deposit markets. In particular, the Fed considers the change and the level of the HerfindahlHirschman Index calculated from deposit shares of all banks in a particular local banking market as a determinant of level of competition in banking markets.

Cetorelli 2002 studies some deposit markets that are highly concentrated and finds evidence that as few as two or three banks competing in the same market are sufficient to create "tough" price competition that would remove monopoly profit. This finding is not surprising given that all banks in the market can compete for customer deposits, and the ability of consumers to access alternative suppliers by car, bus, subway, or the internet.

The concentration of lenders resulting from bank mergers, however, is not emphasized by regulators. The Federal Reserve Board does not extend its anticompetitive analysis of a proposed merger to the lending market. Ensuring that there is no excessive concentration in deposit markets does not preclude market power in at least some segments of the lending market. Theoretical analysis and empirical evidence suggest that lending market concentration may be a bigger area of potential concern than deposit market concentration. ${ }^{1}$ In particular, unlike the deposit market, small banks are unable to compete for large loans (because of diversification concerns and loan-to-one-borrower

\footnotetext{
${ }^{1}$ Cetorelli 2001 provides a review of several theoretical and empirical studies for the positive and negative effects of competition and concentration in banking markets.
} 
regulatory limits). Thus a highly fragmented deposit market may coincide with a market where very few banks are able to provide large loans.

The effects of loan market concentration (defined here as the absence of a sufficient number of local competitors in bank lending) should be heterogeneous across different segments of the loan market. Small borrowers can borrow from all banks, including local community banks. ${ }^{2}$

Very large borrowers typically operate in many different regions of the country, have established track records of creditworthiness with many national or international banks, and often have access to capital markets. Money center banks compete for their business in a borderless environment. Local loan market concentration should have little or no effect on the largest firms' access to credit.

Of greatest concern, then, is the effect of loan market concentration on middlemarket borrowers. We hypothesize that adverse-selection and transaction $\operatorname{costs}^{3}$ can constrain middle-market borrowers to a geographic area with a limited number of potential suppliers (that is, banks large enough to meet their needs). ${ }^{4}$ Thus, middlemarket borrowers are most likely to suffer from allowing monopoly power to be created in their local lending market.

\footnotetext{
${ }^{2}$ Petersen and Rajan 1994, 1995 find evidence that small firms may even benefit from market concentration. Their stylized model demonstrates that monopoly bank can solve adverse selection problem suffered by lenders in a competitive lending market when they are faced with a pool of risky but unknown borrowers. It may be easier in a highly concentrated lending market for lenders to establish lending relationships with relatively less known firms.

${ }^{3}$ Higher transaction costs potentially stem from higher search costs, higher monitoring costs, and higher information gathering costs required for lenders to build business expertise in a particular local lending market.

${ }^{4}$ Degryse and Ongena 2002 provide a review of theoretical papers that show the importance of distance in loan pricing and availability. They also provide empirical evidence in support of that model, using data from Belgium banks.
} 
This study measures the effects of loan market concentration on middle-market borrowers in the clearest case of a merger that reduced competition among large banks within a region - the merger of Fleet and Bank Boston in 1999. We take advantage of the unique circumstances associated with this merger. Notwithstanding the branch divestitures required by regulators to maintain competition in the deposit market, middle-market lending activities in New England became highly concentrated in the hands of the combined Fleet-BankBoston entity after the merger.

For a bank to meet the current and prospective needs of a borrower, it must be of sufficient size such that a loan to that borrower would not constitute an imprudently large risk relative to the equity capital of the lender. Loans to one borrower are limited both by prudence and by regulatory limits on loans to one borrower relative to bank equity. Thus, there tends to be a correlation between the size of the lender and the size of the borrower (as demonstrated in Table I below).

Virtually no other bank with the ability to supply loans of significant size was operating in New England alongside Fleet-BankBoston. Figure I shows the commercial and industrial middle-market lending market shares of the twelve largest Bank Holding Companies located in New England immediately before the merger. Fleet and Bank Boston controlled more than $50 \%$ of the pre-merger market share.

To measure the effects of the merger on loan pricing for middle-market borrowers, we compare all-in-spreads of loans made by Fleet and BankBoston to those of loans made by other lenders to middle-market borrowers located inside and outside of New England for the period before and after the merger using both regression analysis and matched-sample comparison methods. We organize the paper as follows. The next 
section describes our theoretical framework for modeling the relationship between loan pricing and borrower size. Section 3 describes data sources and outlines the research methods used in the paper. Section 4 presents our empirical findings. Conclusions and policy implications are discussed in Section 5.

\section{Borrower Size and Interest Rates on Loans}

Why should the size of a middle market borrower affect the interest rate paid by the borrower? For very small loans, transaction costs of processing loans favor larger borrowers, but this would not have any discernible impact on interest rates over the size range of loans relevant in middle market lending.

Borrower size effects, however, proxy for three potentially important influences: (1) economies of borrower size that reflect economies of scope, (2) diseconomies of borrower size that reflect information costs, and (3) the competitiveness of pricing, which varies with size in a non-monotonic fashion, depending on local market circumstances.

\section{Borrower Size and Economies of Scope}

Economies of scope refer to relationship cost savings that come from selling more than one product to the same customer. Providing multiple products to the same customer economizes on the costs of marketing, reduces the physical costs per product of managing the customer relationship, and economizes on the costs of monitoring customers (by avoiding duplicative monitoring).

Larger firms have more complex needs and typically require more services from their bank. For example, larger firms are more likely to be engaged in exporting, and therefore, may desire to establish accounts abroad or hedge foreign exchange risk. Larger 
firms may decide to have their bank manage their 401-K plan. Larger firms are more likely to enter the public equity market and to use their bank to underwrite securities. Because large firm size is correlated with more product needs, economies of scope will reduce the cost of servicing loans to larger firms, ceteris paribus.

\section{Borrower Size and Information Cost}

The information cost literature (reviewed by Degryse and Ongena 2002) shows the importance of locational proximity for reducing information costs in lending. If a bank's offices are located in one city or region, but a borrower is located partly or entirely outside of that region, the bank will face higher information costs when undertaking due diligence prior to making the loan and when monitoring borrower condition and actions after the loan is made.

Borrower size is positively correlated with the geographic scope of the borrower (i.e., bigger firms will tend to be located in a larger geographic area). Thus, for a bank with offices confined to one region, larger borrower size will proxy for higher information costs. It is also possible that larger borrower size raises information costs even for banks located throughout the geographic range of the borrower, since larger firms, which on average have more diverse locations and types of operations, may be more complex, and therefore, harder to monitor.

\section{Borrower Size and Loan Market Competition}

Borrower size also may affect the degree of competition faced by banks that consider lending to the borrower. A small borrower will be able to consider lending offers from many small banks located close to the borrower. But large borrowers, even if their operations are geographically concentrated in one place, will not be able to borrow 
from small banks because banks require diversified portfolios. Loan-to-one-borrower regulatory limits require that banks limit their loans to any one borrower to a small fraction of their existing book equity. Even without those regulatory limits, banks would voluntarily self-regulate to limit their risk exposures to particular borrowers or industries. In New England during our period of study, Fleet and BankBoston were the only two large bank lenders, but there were many small banks in existence. When Fleet and BankBoston consolidated, competition for small borrowers remained in place because small banks continued to provide that competition. But after their consolidation, large borrowers had to either borrow from Fleet-BankBoston or turn to lenders from outside New England (and those lenders faced a cost disadvantage due to their distant location).

\section{Summary}

When these three considerations are combined, they have the following implications for our study of the cost of making loans to banks, and the pricing of loans to bank borrowers:

(1) Loans to the smallest middle-market borrowers will have lower information costs to local lenders, and those information costs will be passed on to borrowers, both before and after the merger of Fleet-BankBoston, because of the continuing competitiveness of the loan market for those loans. That is, there is a sufficient supply of local lenders to offer economical loans to small borrowers, both before and after the merger.

(2) The combined effect of information cost and economies of scope on loan pricing prior to the merger of Fleet-BankBoston should be to produce a U-shaped relationship between 
loan interest rates and borrower size for Fleet-BankBoston borrowers. In the middling size range, where costs are lowest, borrowers are small enough to be geographically concentrated in New England but large enough to produce significant economies of scope for lenders. Pre-merger competition between Fleet and BankBoston would ensure that at least some of the cost economies of lending to this middling size group of borrowers would be passed on to borrowers. At some sufficiently large borrower size level, the marginal effect of economies of scope diminishes (i.e., at some size threshold, firms are large enough to demand a full range of products), and the marginal effect of the diseconomy of size related to information costs dominates the marginal effect of economies of scope in the cost function.

(3) After the merger of Fleet-BankBoston, the U-shaped relationship should become more of a monotonically increasing relationship. Smaller borrowers continue to enjoy the same competition in the local market (due to the continuing existence of small banks), but after the merger, larger borrowers have no alternative local source of funds to the newly combined Fleet-BankBoston. Consequently, cost savings enjoyed by the new Fleet-BankBoston will not be passed on to those borrowers.

These predicted pre- and post-merger patterns are illustrated in Figure II. Note that after the merger, there is a jump in the pricing function for loans, which raises the cost of loans for medium-sized middle-market borrowers, but not for small- or largesized middle-market borrowers. In Figure II, the pricing function jumps at a point determined by the maximum loan-to-one-borrower limit of the remaining small banks 
(assuming a correspondence between loan size and a borrower's total annual sales). For example, if after the merger the largest of the remaining small banks can only compete for loans to firms with under $\$ 25$ million in sales, then the jump in the pricing function will occur at that level of borrower sales.

\section{Data Sources and Research Methods}

The loan pricing data are constructed from the DealScan database for U.S. borrowers from two periods. The pre-merger period is from 07/01/1996 to 06/30/1999 and the post-merger period is from $01 / 01 / 2000$ to $12 / 31 / 2002$. The six month window of three months before and after the merger (September 1999) is excluded from the sample to allow sufficient time for merger integration to take place. We focus on middle market borrowers, defined as borrowers with annual sales between $\$ 10$ million and $\$ 500$ million. Loan observations, including all-in-spread data, are then matched with Compustat or SEC filings for financial statement information.

The final pre-merger sample consists of 183 and 2,447 loan facilities to firms headquartered inside and outside of the New England states, respectively. ${ }^{5}$ The final postmerger sample consists of 147 New England borrowers' loan facilities and 1,771 nonNew England borrowers' loan facilities. All loans are assigned to a bank. For syndicated loans, the lead lender is identified using the method defined by DealScan, i.e., the top-left name in the loan documentation ${ }^{6}$.

\footnotetext{
${ }^{5} \mathrm{CT}, \mathrm{MA}, \mathrm{ME}, \mathrm{NH}, \mathrm{RI}$, and VT.

${ }^{6}$ By DealScan convention, names listed on the top line are those at agent level such as administrative, documentation and syndication agents. The first name of the top line is typically the lead arranger with pricing power for the loan.
} 
Table II provides descriptive statistics for loans in our sample, both inside and outside of New England, before and after the merger. Table III breaks down the market share of middle-market lending into three sub-categories according to borrower sales size: the small-sized segment of the middle market ( $\$ 10-\$ 100$ million), the medium-sized segment of the middle market (\$100-\$250 million), and the large-sized segment of the middle market (\$250-\$500 million).

For the medium- and large-sized segments of New England middle-market borrowers, the combined market share of Fleet and BankBoston increased from around $40 \%$ before the merger to $52 \%$ and $66 \%$ after the merger respectively, although the amount of their lending to the medium-sized category actually fell substantially. Their market share for the small-sized segment of New England middle-market borrowers decreased from $22 \%$ to $10 \%$ after the merger. The significant amount of branch divestitures required by regulators may have had a negative impact on the market share of Fleet-BankBoston in the small-sized segment of the market.

It is interesting to note the growth in the middle-market lending market share of Fleet-BankBoston outside of New England after the merger. Their overall market share roughly doubled from $8 \%$ to $15 \%$ after the merger. Thus, the merger seems to have encouraged them to expand outside of New England. Interestingly, that expansion largely reflects growth in lending to the largest middle-market borrowers. It may be that the expanded size of the combined Fleet-BankBoston entity allowed it to lower its cost of supplying larger loans (a large loan from the combined entity, after the merger, posed less of a problem for bank diversification than a comparable loan from either bank before the merger). 
Table IV provides summary statistics for the all-in-spread on all loans broken down by size categories, inside and outside of New England, before and after the merger. In New England, Fleet and BankBoston charged 37 and 43 basis points less than their competitors, before and after the merger, respectively. ${ }^{7}$ Outside of New England, loan spreads on Fleet-BankBoston loans were not significantly lower than average before the merger but were 18 basis points lower than competitors after the merger. ${ }^{8}$ Of course, simply looking at the average of all-in-spreads without controlling for the risk characteristics of borrowers or differences in cost associated with different types of loans, and without distinguishing among borrowers of different size, may provide a misleading picture of changes in loan pricing as a result of the merger. Indeed, we will show below that one can detect important changes in pricing policies for some classes of borrowers, once one takes account of changing characteristics in the sample of borrowers and loans.

\section{Simple regressions}

We estimate OLS regression equations predicting the all-in-spreads for loans as a function of loan and borrower risk characteristics. Specifically, we consider the following regression, run separately for loans made to borrowers inside and outside New England.

$$
S P R E A D_{i}=\alpha+\left\{B B F_{i}\left|S M A L L_{i}\right| M E D I U M_{i} \mid P O S T_{i}\right\} \beta^{\text {mdiff }}+X_{i}^{c o n} \beta^{c o n}+u_{i}
$$

where,

$\{. .||\} \quad-$.$\quad creates a vector of proper interaction terms of its elements { }^{9}$,

$B B F \quad-\quad$ is one if BankBoston or Fleet is the lead lender,

POST - $\quad$ is one if the observation is from the post-merger period,

\footnotetext{
${ }^{7}$ Significant at the $1 \%$ level.

${ }^{8}$ Significant at the $1 \%$ level.

${ }^{9}$ Specifically, we run the regression with

$B B F, B B F * S M A L L, B B F * M E D I U M, P O S T * B B F, P O S T * B B F * S M A L L, P O S T * B B F * M E D I U M$.
} 
SMALL - $\quad$ is one if the borrower's sales are between $\$ 10$ and $\$ 100$ million, MEDIUM - $\quad$ is one if the borrower's sales are between $\$ 100$ and $\$ 250$ million, and $X^{c o n}$ contains control variables. We include loan characteristics such as loan size, loan maturity, indicator variables for loan type (revolver, short-term revolver, ${ }^{10}$ and term loans), indicator variables for the purpose of the loan (e.g., working capital, repayment of existing debt, or acquisition finance), an indicator variable for a secured loan, an indicator variable for loans made by sole lenders, and an indicator variable for loans that are indexed by prime rate instead of Libor. ${ }^{11}$ For characteristics of the borrower, we include the equity-to-assets ratio (inverse leverage ratio), sales as measure of borrower size, indicator variables for market credit ratings, and indicator variables for industry and time. The majority of the borrowers in our dataset (95\%) do not have senior debt credit ratings by any major rating agencies. To ensure that we adequately capture and control for the credit risk of borrowers, we include actual credit ratings (when available) and estimated credit ratings for non-rated firms as additional control variables in our regressions. To arrive at estimated credit ratings, we run an ordered Probit regression on loan observations with available ratings as shown in Table $\mathrm{V}$ and then use the estimated equation to forecast credit ratings for the whole sample. ${ }^{12}$

We also run a regression combining all loans inside and outside of New England, rather than separating the two samples, and in that specification we include an additional variable, $N E$, as an indicator for loans to borrowers in New England.

\footnotetext{
${ }^{10}$ Due to difference in regulatory capital requirements between revolve loans with less than one year maturity and loans with more than one year to maturity, separate dummy variables are used to capture the loan pricing difference.

${ }^{11}$ Beim 1996 documents a pricing premium paid by borrowers whose loan spreads are quoted against prime rate over borrowers whose loan spreads are quoted against Libor.

${ }^{12}$ In fact, our results are not sensitive to the omission of the credit rating dummies.
} 
In all of these regressions, the coefficients of $B B F$ and its interaction terms with borrower size can be used to gauge the impact of the merger on borrowers in different size classes.

\section{Two-step Estimators}

Additionally, we estimate a two-step model of loan interest spreads, to control for the potential endogeneity of a borrower's having a relationship with Fleet-BankBoston, where we allow the $\mathrm{BBF}$ indicator to be endogenous. If $\mathrm{BBF}$ is endogenous to borrower characteristics, then that endogeneity could produce selectivity bias and affect our estimates of the effects of BBF on interest cost.

We model $B B F_{i}$ as an outcome of an unobserved latent variable:

$$
\begin{gathered}
B B F_{i}^{*}=Z_{i} \pi+\varepsilon_{i} \\
B B F= \begin{cases}1 & \text { if } B B F^{*}>0 \\
0 & \text { if } B B F^{*} \leq 0\end{cases}
\end{gathered}
$$

where $Z_{i}$ is a vector of exogenous variables, including $X^{\text {con }}$. That is, the matching of borrowers to Fleet and BankBoston is not random and the factors that determine the matching potentially influence the all-in-spread, as well. As the middle-market borrowers are potentially spatially constrained, we include three exogenous distance variables, namely DISTANCE, LATITUDE and LONGITUDE into the first-step Probit regression. DISTANCE measures the mileage distance between the borrower's headquarters and the Fleet or BankBoston corporate headquarters in Boston. LATITUDE and LONGITUDE is simply the map coordinate of the borrower's 
headquarter. In the second-step regression, appropriate hazard terms must be added to (1) and standard errors must be adjusted. ${ }^{13}$

13 Our framework produces the same estimation result as a switching regression with an endogenous selection equation. Under that framework, one assumes there are two underlying loan rate equations, one by $B B F$ and the other by their competitors. The borrowers select one of the lenders based on an endogenous selection equation. Specifically, the problem can be expressed as follows:

(BBF offer rate equation)

$$
\operatorname{SPREAD} D_{i}^{b}=X_{1 i} \beta^{b}+u_{i}^{b}
$$

(Other offer rate equation)

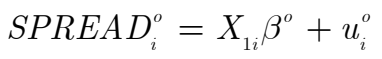

(Selection equation)

$$
\begin{gathered}
B B F_{i}^{*}=X_{2 i} \eta+\alpha^{b} S P R E A D_{i}^{b}+\alpha^{o} S P R E A D_{i}^{o}+v_{i} \\
\begin{array}{c}
S P R E A D_{i}=B B F_{i} \cdot S P R E A D_{i}^{b}+\left(1-B B F_{i}\right) \cdot S P R E A D_{i}^{o} \\
B B F_{i}=1 \text { if } B B F_{i}^{*}>0 \\
=0 \text { if } B B F_{i}^{*} \leq 0
\end{array}
\end{gathered}
$$

where $X_{1 i}$ is a vector containing exogenous variables that determine spread and $X_{2 i}$ is a vector containing exogenous variables that determine a firm's likelihood of borrowing from BankBoston and Fleet. Inserting (i) and (ii) into (iii), we can rewrite (iii) in reduced form as

$$
B B F_{i}^{*}=X_{i} \pi+\varepsilon_{i}
$$

where $X_{i}$ contains all exogenous variables in (i) and (ii). To apply the two-step estimation procedure,

consider the following expressions for conditional expectations of $S P R E A D_{i}^{b}$ and $S P R E A D_{i}^{o}$ given $X_{1 i}$ and $B B F_{i}^{*}$

$$
\begin{gathered}
\mathrm{E}\left(S P R E A D_{i}^{b} \mid X_{1 i}, B B F_{i}^{*}>0\right)=X_{1 i} \beta^{o}+X_{1 i} \theta_{0}+\mathrm{E}\left(u_{i}^{b} \mid X_{1 i}, B B F_{i}^{*}>0\right) \\
\mathrm{E}\left(S P R E A D_{i}^{o} \mid X_{1 i}, B B F_{i}^{*} \leq 0\right)=X_{1 i} \beta^{o}+\mathrm{E}\left(u_{i}^{o} \mid X_{1 i}, B B F_{i}^{*} \leq 0\right)
\end{gathered}
$$

where we define $\theta_{0}=\beta^{b}-\beta^{o}$ so that the null hypothesis of interest can be written as $\mathrm{H}_{0}: \theta_{0}=0$.

Assume joint normality of error terms, which is not required for consistency of two-step estimators, to write out hazard terms explicitly. We have

$$
\begin{aligned}
& \mathrm{E}\left(u_{i}^{b} \mid X_{1 i}, B B F_{i}^{*}>0\right)=\sigma_{v b} \sigma_{v}^{-1} \lambda\left(X_{i} \hat{\pi}\right) \\
& \mathrm{E}\left(u_{i}^{o} \mid X_{1 i}, B B F_{i}^{*} \leq 0\right)=\sigma_{v o} \sigma_{v}^{-1} \lambda\left(-X_{i} \hat{\pi}\right)
\end{aligned}
$$

where $\sigma_{v b}$ is the covariance between $u_{i}^{b}$ and $v_{i}, \sigma_{v o}$ is the covariance between $u_{i}^{o}$ and $v_{i}$, and $\sigma_{v}$ is standard deviation of $v_{i}$. The function $\lambda(\cdot)$ is the inverse Mills ratio and $\hat{\pi}$ is the probit ML estimate of $\pi$ from the first stage regression. The second stage regression can be implemented on all observations in the following OLS regression:

$$
\begin{gathered}
\text { SPREAD }=X_{1 i} \beta^{o}+\left(B B F_{i} \cdot X_{1 i}\right) \theta_{0}+\theta_{1} h_{i}+e_{i} . \\
h_{i}=\left\{\begin{array}{l}
\lambda\left(X_{i} \hat{\pi}\right) \quad ; B B F_{i}=1 \\
\lambda\left(-X_{i} \hat{\pi}\right) ; B B F_{i}=0
\end{array}\right.
\end{gathered}
$$

However, the standard errors from the second-step regression are incorrect and need to be adjusted for the variation introduced by $\hat{\pi}$ in the first stage Probit regression. The standard error adjustment for this problem is essentially that of the generated regressors framework that is treated extensively in the literature (see, for example, Wooldridge 2001 Chapter 6 and Heckman 1979). 


\section{Matched-sample Analysis}

As a robustness test to our regression results, we calculate matching estimators to measure the difference between the average all-in-spread of BBF loans and average allin-spread of non-BBF loans. In our context, we assume that a loan can be grouped into two groups indexed by the $B B F$ variable. Conceptually, each loan $i$ in our sample has a $\operatorname{SPREAD_{i}^{b}}$ that would result if the loan were made by BBF and a $S P R E A D_{i}^{o}$ that would result if the loan were made by other, non-BBF lenders. The quantity of interest is the mean effect of treatment on the treated as commonly used in the program evaluation literature:

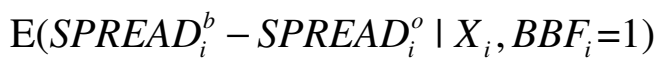

where $X_{i}$ contains all variables that explain the relevant difference between BBF and

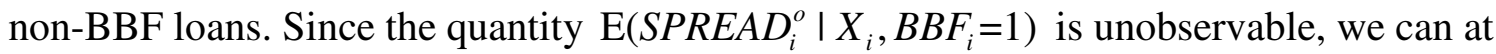
best use its observable counterpart from self-selected non-BBF loans

$$
\mathrm{E}\left(\operatorname{SPREAD} D_{i}^{o} \mid X_{i}, B B F_{i}=0\right)
$$

for our comparison.

As described in Heckman, Ichimura and Todd 1997 and Heckman, Ichimura and Todd 1998, the bias introduced by using

$$
\mathrm{E}\left(\operatorname{SPREAD} D_{i}^{b} \mid X_{i}, B B F_{i}=1\right)-\mathrm{E}\left(S P R E A D_{i}^{o} \mid X_{i}, B B F_{i}=0\right)
$$

instead of (4) to estimate the mean effect of treatment on the treated can be minimized by matching each BBF loan to a subset of non-BBF loans whose propensity scores are closest to the score of that particular BBF loan. In our case, we can simply use the Probit 
regression in the first-step regression of our two-step estimators in the previous section to construct a propensity score $\operatorname{Pr}\left(B B F_{i}=1 \mid X_{i}\right)$ for all loans in our sample. We consider two simple matching estimators in our study: the nearest neighbor and the Gaussian kernel. $^{14}$

\section{Empirical Results}

Table VI presents our main regression results, where New England and the rest of the country are treated separately. The first two columns are the OLS and two-step estimators for the all-in-spread in New England (where the two-step regression uses a first-stage regression that only includes New England borrowers), whereas the last two columns are the corresponding results for loans outside New England (where the two-step regression uses a first-stage regression that only includes borrowers outside New England). The control variables play an important role. The equity to total asset ratio, $E A$, enters the regressions significantly with the expected negative sign. The size of the borrowers, LOGSALES, is also significant and has a negative sign. The variable SECURED is also significantly positive, reflecting the fact that unobservably riskier loans have a greater chance of being secured. Consistent with Beim 1996, we also document a

\footnotetext{
${ }^{14}$ Let $S P R E A D_{i}^{b}$ be the spread of BBF loan $i$. Then, the nearest neighbor matching estimator with parameter $\mathrm{N}$ constructs the average spread of $\mathrm{N}$ non-BBF loans with the closest propensity score as $\overline{\operatorname{SPREAD}}_{i}^{o}=(1 / N) \sum_{j} \operatorname{SPREAD_{j}^{o}} ; j=1, \ldots, N$. The Gaussian kernel matching estimator uses a weighted average of spread of all non-BBF loans by assigning higher weight to loans with closer propensity score to BBF loan i. Specifically, for each non-BBF loan $\mathrm{j}$, the weigh assigned to its spread is $w_{i, j}=\phi\left(\right.$ propensityscore $_{i}^{b}-$ propensityscore $\left._{j}^{o}\right)$, where $\phi$ is normal density. Then, the weighted average spread of non-BBF loans is $\overline{\operatorname{SPREAD}}_{i}^{o}=\sum_{j}\left(w_{i, j} \times \operatorname{SPREAD_{j}^{o}}\right) / \sum_{j} w_{i, j}$. Finally, (6) can be estimated by $\sum_{i}\left(S P R E A D_{i}^{b}-\overline{S P R E A D_{i}^{o}}\right)$.
} 
large and significantly positive coefficient for PRIME, an indicator variable for loans that are quoted relative to prime rate (instead of Libor).

In the OLS regression, we find that, before the merger, loans by Fleet and BankBoston to the small-sized segment of the middle market are priced on average 50 basis points $(-67+17)$ lower than their competitors for otherwise identical loans to New England borrowers. The pre-merger discount for the middle-sized segment of New England's middle-market lending is even greater, averaging 82 basis points $(-99+17)$. There is no discount for the large-sized segment of the middle market. Thus, our empirical results confirm the predicted pre-merger U-Shaped relationship between loan pricing and borrower size for New England borrowers of Fleet and BankBoston. Outside of New England, we find no discount for any category of middle-market borrowers before the merger.

This evidence is consistent with the view that Fleet and BankBoston enjoyed special economies of scale and scope in middle-market lending within New England, which allowed them to underprice other competitors. Competition between them, as the two largest lenders in the region, effectively forced them to pass on their efficiency advantages to borrowers. These efficiency advantages did not extend beyond their own regional market, as is shown by the results for loans outside of New England.

After the merger, the discount for the small-sized segment of middle-market borrowers increases slightly (but not statistically significantly) to 84 basis points $(-67+$ $17-18$ - 16). For the medium-sized segment, however, the pre-merger discount disappears. This result demonstrates the post-merger exercise of market power within New England, and shows that it only occurs within the middle-sized category of middle- 
market borrowers. The market for loans to small-sized borrowers is still competitive (as it contains many small banks especially as a result of asset divestiture), and the loan market for large-sized borrowers is as competitive as it used to be before the merger because those borrowers have access to national capital markets and to large banks in other regions.

The results from two-step regressions are similar to the OLS results. In fact, the coefficient of the inverse Mills ratio in the second-step regression for New England loans is not significant, rejecting the presence of endogeneity bias from $B B F$. Even though the coefficient of the inverse Mills ratio for loans from outside of New England is highly significant, the only noticeable difference between two-step and OLS regression is that the coefficient of the $B B F$ variable becomes positively significant (28 basis points), which affects loan spreads of middle-market borrowers of all sizes. Table VIII shows the first-step Probit regression where we include the log of distance (in miles) between the borrower and Boston, LDIST, and its square term together with the latitude and longitude of the borrowers' headquarters. ${ }^{15}$ Our choice of these instruments reflects our assumption that middle-market borrowers are spatially constrained and select their lenders partially based on their location.

In addition, we run OLS and two-step regressions combining all loans from inside and outside of New England, together with an indicator variable for loans from borrowers within New England, NE. The results are similar and are reported in Table VII. To test whether our results are sensitive to our choice of the size cut-offs for the small, middle

\footnotetext{
${ }^{15}$ Using the range of distance between Fleet-BankBoston headquarter and borrowers within the U.S. in the sample, the net marginal effect of distance on $\operatorname{Pr}(\mathrm{BBF}=1)$ estimates is negative both inside and outside of New England. The variables Latitude and Longitude are significant for regressions of loans outside of New England and combined loan observations, but their economic significance is very small.
} 
and large segments of middle-market borrowers, we replaced discrete indicator variables for the size of borrowers, which interact with $B B F$, with the continuous measures, LOGSALES and LOGSALES squared. The results are qualitatively similar and are not reported here.

As a robustness test, we also apply the econometric matching methods of Heckman, Ichimura and Todd 1997 and Heckman, Ichimura and Todd 1998 to our data, as described above. The results are shown in Table IX for the Gaussian kernel estimator. The results are very similar for nearest neighbors (with $\mathrm{N}=1$ ), and thus are not reported here. Within small-sized and medium-sized segments of New England borrowers before the merger, non-BBF loans are priced on average 56 and 94 basis points higher than the corresponding BBF loans respectively. After the merger, the BBF discount increases to 89 basis points for the small-sized borrowers but disappears for the medium-sized segment of the market. Consistent with the regression results, there is no discount in loan pricing for the large-sized segment of middle-market borrowers before or after the merger, nor is there a discount for non-New England loans.

\section{Conclusions}

Our findings that Fleet and BankBoston offered pre-merger interest rate discounts to medium-sized borrowers in middle market lending in New England, and that the discount disappeared after the merger, indicate several important points. First, large universal banks seem to enjoy location-specific economies with small- and medium-sized middle-market borrowers. 
Second, the pre-merger pricing for middle-market borrowers indicates that the banking market can be very "competitive," even when it is highly concentrated. Fleet and BankBoston competed away nearly a full percentage point of their cost advantages in the medium-sized segment of the middle-market loan market prior to the merger, even though they were the only two large banks in New England. That result is consistent with Cetorelli's (2002) finding for deposit market competition. Kreps and Scheinkman (1983) show that, in theory, the extent to which oligopolistic competition results in lower pricing depends on the costs of generating both capacity and production. The Bertrand equilibrium in which price competition between duopolists results in the perfectly competitive outcome depends on the ability of the duopolists to produce whatever is demanded. That assumption requires firms to be able to increase capacity rapidly at no cost. In banking, lending capacity is dictated by the availability of equity capital and human capital (lending officers). Given the ability to shift both equity capital and human capital across different lending niches (defined by sizes and locations of borrowers) it is reasonable to view capacity in any one lending niche as relatively easy to expand. In such a circumstance, it is not surprising that competition between two banks would produce significant cost savings for affected borrowers relative to monopolistic pricing.

Third, once Fleet and BankBoston merged, the economies of information and product scope that large universal banks can realize no longer accrued to borrowers, and instead became captured by the consolidated entity.

Fourth, competition for smaller firms' loans was not affected by the merger. After the merger, the combined entity controlled about half of the loans made to middle-market lenders in New England. Discounts on middle-sized middle-market loans in New 
England disappeared after the merger, but not on small loans, indicating that competition remained strong for small borrowers (who could borrow from small banks as well as large ones), but that middle-sized middle-market borrowers in New England had limited alternatives to the combined Fleet-BankBoston entity after the merger since they are spatially constrained.

In the 1970s and 1980s, many advocates of the elimination of branching restrictions envisioned a new banking structure for the United States consisting of a competitive, nationwide branching system, dominated by many universal banks. While some regions have seen an increase in competition resulting from branching, others have not. In some regions, given the initial conditions of bank fragmentation, and the barriers to entry into new regions posed by an absence of a preexisting set of customer relationships, consolidation has resulted in reduced competition in some regional loan markets, with New England being an extreme case.

Our results suggest that the Fed could expand its anticompetitive study of merger proposals to consider the lending side of the banking business, and could look at particular niches within the lending market when examining anti-competitive effects of a merger. At a minimum, the equivalent version of a Herfindahl-Hirschman index for deposit markets could be calculated for middle-market loans in the areas in which the merger candidates are operating. The availability of loan data, such as those used in this paper, makes it possible to perform such an analysis. ${ }^{16}$

\footnotetext{
${ }^{16}$ The analysis of loan pricing using the DealScan database in this study requires a substantial amount of manual matching of loan observations to other data sources due to the lack of variables that link loan pricing data to lender and borrower financial information. We suggest a few additions to the data fields available in LPC DealScan database that will make such linking more accurate and automated, and thus will make regulatory use of such data more viable. First, FDIC CERT ID or Federal Reserve RSSD ID of the lenders in the loan should be collected at the time of loan filing with DealScan. These variables enable us to link DealScan data to bank financial data, holding structure, and merger information at the FDIC or
} 
Divestiture requirements could take into account the need to support a competitive lending market for middle-market borrowers. Doing so may require not only that the merging institutions divest some branches, but that they also divest a significant number of middle-market lending relationships so that the divested assets and capabilities of the merging institutions be sufficient in size and scope to ensure that a large entrant would be interested in bidding on them. In the Fleet-BankBoston merger, this was not done. Instead, branches were spun off to small banks to ensure sufficient fragmentation of the deposit market.

Achieving a change in merger approval and divestiture policy may require more than regression evidence. Merger policy is also affected by political pressures brought to bear on regulators by banks and politicians. The failure to attract a large entrant as a purchaser of divested assets was not the result of the failure to anticipate the effects of the merger. One of the authors of this study (Calomiris 1999) acted as a consultant to the governments of Massachusetts and Connecticut prior to the Fleet-BankBoston merger. Based on regression analysis of only the pre-merger sample of middle-market borrowers in New England, he advised regulators, in an opinion filed on July 20, 1999, that:

The highest risk of costs to the public from this merger comes from the potential destruction of competition for middle market relationships. In these areas competition favors large banks because of economies of scale and scope. It is crucial, therefore, that a viable competitor of substantial size and technical capability be able to credibly bid for, and continue, a competitive large-scale bank (in particular, one with middle market lending capability) alongside the new merged entity.....

...the Federal Reserve Board's approach to measuring market concentration - which focuses on local deposit concentration - is fundamentally flawed and especially inadequate for measuring the potential effects on competition in particular bank niches (e.g., middle-market lending)....

Federal Reserve System. Second, when possible, DealScan should identify a unique identification number of the borrower (such as Compustat GVKEY or CRSP PERMNO) that can be linked to the borrower's financial data. 
The regressions indicate that Fleet and BankBoston currently possess significant cost advantages, which translate into more than a full percentage point relative to their competitors....in the absence of continuing competition by at least two such banks in the New England area, those cost advantages would not be passed on in the same way to bank customers, since competitive pressures would be lacking. If the two banks could combine, and if no new entrant with similar scale, scope, and geographic presence were to enter, significantly higher interest costs would result.

Despite that evidence, and despite much opposition from middle-market borrowers in New England at the time, who feared that they would suffer higher rates from the merger and voiced that fear to the authorities, there was little chance of stopping Fleet and BankBoston from merging, or of forcing them to divest a large chunk of their middle-market business. According to some sources, Fleet, BankBoston, and some of the smaller banks that anticipated gains from being able to acquire some divested branches enlisted the help of influential members of Congress to pressure the Justice Department and the Fed to ignore arguments made by experts, middle-market borrowers, and state government officials that divestiture should be handled differently. 


\section{REFERENCES}

Beim, D.O. “The Prime Premium: Is Relationship Banking Too Costly for Some?", Columbia Business School Working Paper, 1996.

Calomiris, C.W. "Statement of Charles W. Calomiris, Ph.D.” July 20, 1999.

Calomiris, C.W. "Regulation, Industrial Structure, and Instability in U.S. Banking: An Historical Perspective" in U.S. Bank Deregulation in Historical Perspective, New York, Cambridge University Press, 2000, 1-92, originally published in Michael Klausner and Lawrence White (eds.), Structural Change in Banking, New York University, New York 1993, 19-116.

Calomiris, C.W., Karceski, J., "Is the Bank Merger Wave of the 1990s Efficient? Lessons from Nine Case Studies," in Steven N. Kaplan (ed.), Mergers and Productivity, Chicago, University of Chicago Press, 2000, 93-178.

Cetorelli, N. "Competition Among Banks: Good or Bad?” Federal Reserve Bank of Chicago, Economic Perspectives, 2Q 2001.

Cetorelli, N. "Entry and Competition in Highly Concentrated Banking Markets" Federal Reserve Bank of Chicago, Economic Perspectives, 4Q 2002.

Degryse, H., Ongena, S. "Distance, Lending Relationships, and Competition" Centre for Studies in Economics and Finance, Working Paper No. 80, March 2002.

Evanoff, D., Fortier, D. "Reevaluation of Structure-Conduct-Performance Paradigm in Banking” Journal of Financial Research, I, June 1988, 277-294.

Flannery, M. "The Social Costs of Unit Banking Restrictions" Journal of Monetary Economics, 13 (1984), 237-249. 
Heckman, J. "Sample Selection Bias as a Specification Error", Econometrica, 47, 1, January 1979, 153-162.

Heckman, J., Ichimura, H., Todd, P., "Matching as an Econometric Evaluation Estimator: Evidence from Evaluating a Job Training Programme", Review of Econometric Studies, 1997, 64, 605-654.

Heckman, J., Ichimura, H., Todd, P., "Matching as an Econometric Evaluation Estimator", Review of Econometric Studies, 1998, 65, 261-294.

Hubbard, G, Palia, D. "Executive Pay and Performance: Evidence from the U.S. Banking Industry” Journal of Financial Economics, XXXIX, 1995, 105-130.

Jayaratne, J., Strahan, P. E. “Entry Restrictions, Industry Evolution and Dynamic Efficiency: Evidence from Commercial Banking” Federal Reserve Bank of New York, Research Paper No. 9630, August 1996.

Kreps, D.M., and Scheinkman, J.A. "Quantity Precommitment and Bertrand Competition Yield Cournot Outcomes," Bell Journal of Economics, 1983, 14, 326-38.

Peterson, M.A., Rajan R.G. “The Benefits of Lending Relationship: Evidence from Small Business Data" Journal of Finance, 1994, 49, 3-37.

Peterson, M.A., Rajan R.G. “The Effect of Credit Market Competition on Lending Relationships" Quarterly Journal of Economics, 1995, 110, 406-443.

Wooldridge, J. M. Econometric Analysis of Cross Section and Panel Data, First Edition, MIT Press, October 2001. 
Table I

Number of Loans from Lenders to Borrowers of Different Sizes

This table shows the number of loans broken down by lender and borrower size. The data are from the Loan Pricing Corporation database for the period of 07/01/1996 - 06/30/1999 (the pre-merger period) and 01/01/2000 - 12/31/2002 (the post-merger period). The sample borrowers have sales between $\$ 10$ and $\$ 500$ million and are broken down into three size classifications. The lenders are also classified into three size catagories according to aggregate loans extended to U.S. borrowers during a given calendar year.

\begin{tabular}{|c|c|c|c|c|}
\hline & \multicolumn{4}{|c|}{ Lender Size (Total Loans \$ Million) } \\
\hline & $>10000$ & $500-10000$ & $<500$ & All Lenders \\
\hline \multicolumn{5}{|c|}{ PANEL A: New England Pre-merger } \\
\hline Borrower Sales (\$ Million) 250 - 500 & 33 & 17 & 3 & 53 \\
\hline - column $\%$ & $35 \%$ & $26 \%$ & $20 \%$ & $30 \%$ \\
\hline Borrower Sales (\$ Million) $100-250$ & 32 & 26 & 6 & 64 \\
\hline - column $\%$ & $34 \%$ & $39 \%$ & $40 \%$ & $36 \%$ \\
\hline Borrower Sales (\$ Million) $10-100$ & 30 & 23 & 6 & 59 \\
\hline - column \% & $32 \%$ & $35 \%$ & $40 \%$ & $34 \%$ \\
\hline All Borrowers & 95 & 66 & 15 & 176 \\
\hline \multicolumn{5}{|c|}{ PANEL B: New England Post-merger } \\
\hline Borrower Sales (\$ Million) $250-500$ & 69 & 22 & 5 & 96 \\
\hline - column $\%$ & $32 \%$ & $18 \%$ & $6 \%$ & $23 \%$ \\
\hline Borrower Sales (\$ Million) 100 - 250 & 67 & 42 & 24 & 133 \\
\hline - column $\%$ & $31 \%$ & $34 \%$ & $30 \%$ & $32 \%$ \\
\hline Borrower Sales (\$ Million) $10-100$ & 77 & 61 & 52 & 190 \\
\hline - column $\%$ & $36 \%$ & $49 \%$ & $64 \%$ & $45 \%$ \\
\hline All Borrowers & 213 & 125 & 81 & 419 \\
\hline \multicolumn{5}{|c|}{ PANEL C: Outside of New England Pre-merger } \\
\hline Borrower Sales (\$ Million) $250-500$ & 487 & 350 & 34 & 871 \\
\hline - column $\%$ & $36 \%$ & $34 \%$ & $12 \%$ & $32 \%$ \\
\hline Borrower Sales (\$ Million) 100 - 250 & 552 & 356 & 94 & 1,002 \\
\hline - column $\%$ & $40 \%$ & $34 \%$ & $34 \%$ & $37 \%$ \\
\hline Borrower Sales (\$ Million) $10-100$ & 328 & 330 & 150 & 808 \\
\hline - column $\%$ & $24 \%$ & $32 \%$ & $54 \%$ & $30 \%$ \\
\hline All Borrowers & 1,367 & 1,036 & 278 & 2,681 \\
\hline \multicolumn{5}{|c|}{ PANEL D: Outside of New England Post-merger } \\
\hline Borrower Sales (\$ Million) $250-500$ & 922 & 528 & 101 & 1,551 \\
\hline - column $\%$ & $34 \%$ & $25 \%$ & $15 \%$ & $28 \%$ \\
\hline Borrower Sales (\$ Million) $100-250$ & 942 & 712 & 170 & 1,824 \\
\hline - column $\%$ & $35 \%$ & $33 \%$ & $25 \%$ & $33 \%$ \\
\hline Borrower Sales (\$ Million) $10-100$ & 814 & 908 & 399 & 2,121 \\
\hline - column $\%$ & $30 \%$ & $42 \%$ & $60 \%$ & $39 \%$ \\
\hline All Borrowers & 2,678 & 2,148 & 670 & 5,496 \\
\hline
\end{tabular}


Table II

Descriptive Statistics of the Sample Loans Included in the Regression Analysis

The sample data are loan facilities constructed from the Loan Pricing Corporation's DealScan database for borrowers located in the U.S. The pre-merger period is between $07 / 01 / 1996$ and $06 / 30 / 1999$. The post-merger period is between $01 / 01 / 2000$ and $12 / 31 / 2002$. The window period of 6 months - 3 months before and 3 months after the merger - are dropped from the sample. The sample borrowers have annual sales between $\$ 10$ - $\$ 500$ million USD with financial data available in COMPUSTAT or SEC filings and also have all-inspread information available. The pre-merger sample consists of 183 and 2,447 loan facilities inside and outside of New England states respectively. The post-merger sample consists of 147 and 1,771 loan facilities inside and outside of New England states. The variables are defined as in table VI.

\begin{tabular}{|c|c|c|c|c|c|c|c|c|c|c|c|c|}
\hline \multicolumn{13}{|c|}{ PANEL A: ALL BORROWERS } \\
\hline & \multicolumn{6}{|c|}{ New England Borrowers } & \multicolumn{6}{|c|}{ Outside New England Borrowers } \\
\hline Borrowers and Loans & \multicolumn{3}{|c|}{ Pre-merger } & \multicolumn{3}{|c|}{ Post-merger } & \multicolumn{3}{|c|}{ Pre-merger } & & Post-merge & \\
\hline Characteristics & Mean & Std Dev & Median & Mean & Std Dev & Median & Mean & Std Dev & Median & Mean & Std Dev & Median \\
\hline SALES (\$ million) & 174 & 139 & 150 & 172 & 131 & 124 & 168 & 134 & 126 & 197 & 142 & 166 \\
\hline AMT (\$ million) & 84 & 121 & 27 & 65 & 123 & 20 & 80 & 135 & 35 & 88 & 166 & 40 \\
\hline EA & 0.44 & 0.32 & 0.49 & 0.45 & 0.24 & 0.48 & 0.41 & 0.28 & 0.44 & 0.41 & 0.28 & 0.44 \\
\hline MATURITY & 1334 & 914 & 1096 & 1130 & 574 & 1096 & 1373 & 870 & 1130 & 1183 & 684 & 1096 \\
\hline DISTANCE & 74 & 125 & 43 & 60 & 56 & 27 & 1277 & 863 & 1123 & 1293 & 825 & 1159 \\
\hline WORKINGCAP & 0.15 & & & 0.34 & & & 0.09 & & & 0.23 & & \\
\hline RPAYDEBT & 0.30 & & & 0.29 & & & 0.39 & & & 0.26 & & \\
\hline ACQUISITION & 0.27 & & & 0.12 & & & 0.24 & & & 0.15 & & \\
\hline SOLELEND & 0.28 & & & 0.10 & & & 0.25 & & & 0.10 & & \\
\hline TERM & 0.14 & & & 0.12 & & & 0.11 & & & 0.11 & & \\
\hline STREVOLVER & 0.27 & & & 0.28 & & & 0.27 & & & 0.29 & & \\
\hline SECURED & 0.84 & & & 0.90 & & & 0.87 & & & 0.90 & & \\
\hline RATEFORECAST & 0.93 & & & 0.96 & & & 0.94 & & & 0.92 & & \\
\hline PRIME & 0.15 & & & 0.12 & & & 0.17 & & & 0.16 & & \\
\hline SMALL & 0.40 & & & 0.43 & & & 0.43 & & & 0.34 & & \\
\hline MEDIUM & 0.32 & & & 0.26 & & & 0.31 & & & 0.32 & & \\
\hline & & & & PANEI & B: SMAL & L BORRO & & & & & & \\
\hline & & & ew Englan & Borrowe & & & & Outsic & de New En & land Borr & rowers & \\
\hline Borrowers and Loans & & Pre-merger & & & ost-merge & & & Pre-merger & & & Post-merge & \\
\hline Characteristics & Mean & Std Dev & Median & Mean & Std Dev & Median & Mean & Std Dev & Median & Mean & Std Dev & Median \\
\hline SALES (\$ million) & 46 & 25 & 43 & 56 & 27 & 54 & 51 & 26 & 49 & 52 & 26 & 52 \\
\hline AMT (\$ million) & 28 & 56 & 10 & 14 & 38 & 5 & 36 & 74 & 10 & 35 & 71 & 10 \\
\hline EA & 0.50 & 0.24 & 0.48 & 0.53 & 0.17 & 0.54 & 0.43 & 0.29 & 0.45 & 0.47 & 0.28 & 0.51 \\
\hline MATURITY & 1223 & 803 & 1105 & 953 & 546 & 740 & 1212 & 838 & 1095 & 1095 & 712 & 1095 \\
\hline DISTANCE & 63 & 142 & 26 & 60 & 54 & 27 & 1330 & 874 & 1196 & 1320 & 860 & 1185 \\
\hline WORKINGCAP & 0.15 & & & 0.41 & & & 0.13 & & & 0.26 & & \\
\hline RPAYDEBT & 0.23 & & & 0.25 & & & 0.37 & & & 0.28 & & \\
\hline ACQUISITION & 0.27 & & & 0.05 & & & 0.19 & & & 0.12 & & \\
\hline SOLELEND & 0.58 & & & 0.19 & & & 0.44 & & & 0.21 & & \\
\hline TERM & 0.14 & & & 0.14 & & & 0.11 & & & 0.12 & & \\
\hline STREVOLVER & 0.30 & & & 0.32 & & & 0.29 & & & 0.32 & & \\
\hline SECURED & 0.91 & & & 0.94 & & & 0.95 & & & 0.95 & & \\
\hline RATEFORECAST & 1.00 & & & 1.00 & & & 0.96 & & & 0.98 & & \\
\hline PRIME & 0.27 & & & 0.19 & & & 0.31 & & & 0.33 & & \\
\hline & & & & PANEL & C: MEDIL & M BORR & & & & & & \\
\hline & & & ew Englan & Borrowe & & & & Outsic & de New En & land Borr & rowers & \\
\hline Borrowers and Loans & & Pre-merger & & & ost-merget & & & Pre-merger & & & Post-merge & \\
\hline Characteristics & Mean & Std Dev & Median & Mean & Std Dev & Median & Mean & Std Dev & Median & Mean & Std Dev & Median \\
\hline SALES (\$ million) & 169 & 36 & 178 & 159 & 41 & 159 & 169 & 45 & 163 & 168 & 43 & 166 \\
\hline AMT (\$ million) & 99 & 127 & 35 & 77 & 156 & 28 & 93 & 161 & 50 & 80 & 126 & 40 \\
\hline EA & 0.52 & 0.22 & 0.54 & 0.40 & 0.23 & 0.44 & 0.41 & 0.27 & 0.44 & 0.39 & 0.32 & 0.43 \\
\hline MATURITY & 1438 & 1095 & 1096 & 1165 & 580 & 1096 & 1451 & 905 & 1301 & 1193 & 631 & 1096 \\
\hline DISTANCE & 76 & 144 & 43 & 68 & 59 & 40 & 1246 & 895 & 1042 & 1384 & 826 & 1326 \\
\hline WORKINGCAP & 0.14 & & & 0.24 & & & 0.08 & & & 0.22 & & \\
\hline RPAYDEBT & 0.32 & & & 0.50 & & & 0.39 & & & 0.28 & & \\
\hline ACQUISITION & 0.27 & & & 0.13 & & & 0.26 & & & 0.19 & & \\
\hline SOLELEND & 0.12 & & & 0.08 & & & 0.14 & & & 0.05 & & \\
\hline TERM & 0.17 & & & 0.08 & & & 0.11 & & & 0.08 & & \\
\hline STREVOLVER & 0.20 & & & 0.32 & & & 0.25 & & & 0.29 & & \\
\hline SECURED & 0.81 & & & 0.92 & & & 0.84 & & & 0.89 & & \\
\hline RATEFORECAST & 0.86 & & & 0.97 & & & 0.91 & & & 0.90 & & \\
\hline PRIME & 0.07 & & & 0.13 & & & 0.06 & & & 0.10 & & \\
\hline & & & & PANEI & D: LARG & E BORRO & & & & & & \\
\hline & & & ew Englan & Borrowe & & & & Outsic & de New En & land Borr & rowers & \\
\hline Borrowers and Loans & & Pre-merger & & & ost-merge & & & Pre-merger & & & Post-merge & \\
\hline Characteristics & Mean & Std Dev & Median & Mean & Std Dev & Median & Mean & Std Dev & Median & Mean & Std Dev & Median \\
\hline SALES (\$ million) & 371 & 70 & 367 & 341 & 73 & 322 & 363 & 72 & 357 & 368 & 73 & 361 \\
\hline AMT (\$ million) & 150 & 147 & 111 & 124 & 142 & 72 & 137 & 153 & 100 & 149 & 233 & 75 \\
\hline EA & 0.25 & 0.43 & 0.36 & 0.39 & 0.29 & 0.44 & 0.39 & 0.28 & 0.42 & 0.37 & 0.24 & 0.39 \\
\hline MATURITY & 1375 & 832 & 1544 & 1344 & 537 & 1375 & 1550 & 835 & 1815 & 1262 & 694 & 1096 \\
\hline DISTANCE & 89 & 52 & 116 & 53 & 57 & 26 & 1224 & 799 & 1046 & 1182 & 776 & 1054 \\
\hline WORKINGCAP & 0.18 & & & 0.33 & & & 0.04 & & & 0.21 & & \\
\hline RPAYDEBT & 0.38 & & & 0.17 & & & 0.42 & & & 0.21 & & \\
\hline ACQUISITION & 0.28 & & & 0.22 & & & 0.30 & & & 0.16 & & \\
\hline SOLELEND & 0.02 & & & 0.00 & & & 0.05 & & & 0.03 & & \\
\hline TERM & 0.12 & & & 0.11 & & & 0.11 & & & 0.12 & & \\
\hline STREVOLVER & 0.30 & & & 0.20 & & & 0.27 & & & 0.28 & & \\
\hline SECURED & 0.76 & & & 0.85 & & & 0.79 & & & 0.87 & & \\
\hline RATEFORECAST & 0.90 & & & 0.89 & & & 0.92 & & & 0.89 & & \\
\hline PRIME & 0.08 & & & 0.02 & & & 0.05 & & & 0.05 & & \\
\hline
\end{tabular}


Table III

Total Loan Volume Extended to Borrowers Based in the U.S. by Sales Size

The table is constructed from DealScan database and includes all loans regardless of the availability of all-in-spread and balance sheet data. The loan is allocated to BankBoston or Fleet if either of these banks is the lead lender as identified by LPC or is the sole lender for the deal or holds the leading role in syndication with the following titles: administrative, syndication, or documentation agent. The volume numbers are in millions of dollars.

\begin{tabular}{|c|c|c|c|c|}
\hline \multicolumn{5}{|c|}{ Sale Size (\$Million) } \\
\hline & $10-100$ & $100-250$ & $250-500$ & Total \\
\hline \multicolumn{5}{|c|}{ Panel A: New England Pre-merger } \\
\hline Fleet or BankBoston & 1,423 & 4,605 & 5,450 & 11,477 \\
\hline - row $\%$ & $12 \%$ & $40 \%$ & $47 \%$ & \\
\hline - column \% & $22 \%$ & $41 \%$ & $40 \%$ & $37 \%$ \\
\hline Other Banks & 5,076 & 6,584 & 8,243 & 19,902 \\
\hline - row $\%$ & $26 \%$ & $33 \%$ & $41 \%$ & \\
\hline - column \% & $78 \%$ & $59 \%$ & $60 \%$ & $63 \%$ \\
\hline All Lenders & 6,498 & 11,188 & 13,693 & 31,379 \\
\hline - row \% & $21 \%$ & $36 \%$ & $44 \%$ & \\
\hline \multicolumn{5}{|c|}{ Panel B: New England Post-merger } \\
\hline FleetBoston & 1,032 & 3,498 & 8,997 & 13,527 \\
\hline - row $\%$ & $8 \%$ & $26 \%$ & $67 \%$ & \\
\hline - column \% & $10 \%$ & $52 \%$ & $66 \%$ & $44 \%$ \\
\hline Other Banks & 9,292 & 3,254 & 4,690 & 17,236 \\
\hline - row $\%$ & $54 \%$ & $19 \%$ & $27 \%$ & \\
\hline - column \% & $90 \%$ & $48 \%$ & $34 \%$ & $56 \%$ \\
\hline All Lenders & 10,324 & 6,752 & 13,687 & 30,763 \\
\hline - row $\%$ & $34 \%$ & $22 \%$ & $44 \%$ & \\
\hline \multicolumn{5}{|c|}{ Panel C: Outside of New England Pre-merger } \\
\hline Fleet or BankBoston & 12,164 & 17,053 & 12,828 & 42,045 \\
\hline - row $\%$ & $29 \%$ & $41 \%$ & $31 \%$ & \\
\hline - column $\%$ & $8 \%$ & $9 \%$ & $6 \%$ & $8 \%$ \\
\hline Other Banks & 135,023 & 165,100 & 216,950 & 517,073 \\
\hline - row $\%$ & $26 \%$ & $32 \%$ & $42 \%$ & \\
\hline - column $\%$ & $92 \%$ & $91 \%$ & $94 \%$ & $92 \%$ \\
\hline All Lenders & 147,187 & 182,153 & 229,778 & 559,118 \\
\hline - row $\%$ & $26 \%$ & $33 \%$ & $41 \%$ & \\
\hline \multicolumn{5}{|c|}{ Panel D: Outside of New England Post-merger } \\
\hline FleetBoston & 17,523 & 20,207 & 28,059 & 65,788 \\
\hline - row \% & $27 \%$ & $31 \%$ & $43 \%$ & \\
\hline - column \% & $15 \%$ & $15 \%$ & $15 \%$ & $15 \%$ \\
\hline Other Banks & 102,874 & 114,998 & 156,648 & 374,520 \\
\hline - row $\%$ & $27 \%$ & $31 \%$ & $42 \%$ & \\
\hline - column $\%$ & $85 \%$ & $85 \%$ & $85 \%$ & $85 \%$ \\
\hline All Lenders & 120,397 & 135,204 & 184,707 & 440,309 \\
\hline - row $\%$ & $27 \%$ & $31 \%$ & $42 \%$ & \\
\hline
\end{tabular}


Table IV

All-in-Spread Characteristics of All Loan Deals by Borrower Sales Size

The table is constructed from all loan deals in the DealScan database with all-in-spread information available. The loan is allocated to BankBoston or Fleet if either of these banks is the lead lender as identified by LPC or is the sole lender for the deal or holds the leading role in syndication with the following titles: administrative, syndication, documentation agent. The spread numbers are in basis points.

\begin{tabular}{|c|c|c|c|c|}
\hline \multicolumn{5}{|c|}{ Sale Size (\$Million) } \\
\hline & $10-100$ & $100-250$ & $250-500$ & Total \\
\hline \multicolumn{5}{|c|}{ Panel A: New England Pre-merger } \\
\hline \multicolumn{5}{|l|}{ Fleet or Bank Boston } \\
\hline - Average All-in-Spread & 240 & 181 & 201 & 209 \\
\hline - Standard Deviation & 87 & 96 & 131 & 107 \\
\hline - Number of Deals & 73 & 65 & 51 & 189 \\
\hline \multicolumn{5}{|l|}{ Other Banks } \\
\hline - Average All-in-Spread & 289 & 228 & 198 & 246 \\
\hline - Standard Deviation & 132 & 106 & 121 & 127 \\
\hline - Number of Deals & 105 & 97 & 78 & 280 \\
\hline \multicolumn{5}{|l|}{ All Lenders } \\
\hline - Average All-in-Spread & 269 & 206 & 199 & 229 \\
\hline - Standard Deviation & 117 & 104 & 126 & 120 \\
\hline - Number of Deals & 178 & 162 & 129 & 469 \\
\hline \multicolumn{5}{|c|}{ Panel B: New England Post-merger } \\
\hline \multicolumn{5}{|l|}{ Fleet or Bank Boston } \\
\hline - Average All-in-Spread & 245 & 228 & 222 & 229 \\
\hline - Standard Deviation & 93 & 124 & 158 & 133 \\
\hline - Number of Deals & 35 & 54 & 56 & 145 \\
\hline \multicolumn{5}{|l|}{ Other Banks } \\
\hline - Average All-in-Spread & 271 & 288 & 245 & 272 \\
\hline - Standard Deviation & 109 & 179 & 99 & 133 \\
\hline - Number of Deals & 137 & 65 & 46 & 248 \\
\hline \multicolumn{5}{|l|}{ All Lenders } \\
\hline - Average All-in-Spread & 266 & 261 & 230 & 255 \\
\hline - Standard Deviation & 107 & 160 & 140 & 135 \\
\hline - Number of Deals & 172 & 119 & 102 & 393 \\
\hline \multicolumn{5}{|c|}{ Panel C: Outside of New England Pre-merger } \\
\hline \multicolumn{5}{|l|}{ Fleet or Bank Boston } \\
\hline - Average All-in-Spread & 259 & 223 & 211 & 235 \\
\hline - Standard Deviation & 88 & 85 & 83 & 88 \\
\hline - Number of Deals & 245 & 241 & 138 & 624 \\
\hline \multicolumn{5}{|l|}{ Other Banks } \\
\hline - Average All-in-Spread & 264 & 216 & 190 & 229 \\
\hline - Standard Deviation & 114 & 99 & 106 & 111 \\
\hline - Number of Deals & 2,594 & 2,122 & 1,727 & 6,443 \\
\hline \multicolumn{5}{|l|}{ All Lenders } \\
\hline - Average All-in-Spread & 264 & 217 & 192 & 230 \\
\hline - Standard Deviation & 111 & 97 & 104 & 109 \\
\hline - Number of Deals & 2,839 & 2,363 & 1,865 & 7,067 \\
\hline \multicolumn{5}{|c|}{ Panel D: Outside of New England Post-merger } \\
\hline \multicolumn{5}{|l|}{ Fleet or Bank Boston } \\
\hline - Average All-in-Spread & 255 & 263 & 240 & 253 \\
\hline - Standard Deviation & 82 & 103 & 102 & 96 \\
\hline - Number of Deals & 199 & 187 & 181 & 567 \\
\hline \multicolumn{5}{|l|}{ Other Banks } \\
\hline - Average All-in-Spread & 288 & 270 & 247 & 271 \\
\hline - Standard Deviation & 120 & 120 & 133 & 125 \\
\hline - Number of Deals & 1,789 & 1,439 & 1,142 & 4,370 \\
\hline \multicolumn{5}{|l|}{ All Lenders } \\
\hline - Average All-in-Spread & 284 & 269 & 246 & 269 \\
\hline - Standard Deviation & 117 & 118 & 129 & 122 \\
\hline - Number of Deals & 1,988 & 1,626 & 1,323 & 4,937 \\
\hline
\end{tabular}


Table V

Ordered Probit Regression Predicting Bond Rating for Missing Observations

This table presents a simple ordered probit regression predicting senior debt rating for borrowers with no credit rating data available from DealScan database. The numerical codes for rating are: $0=C C C, 1=B$, $2=\mathrm{BB}, 3=\mathrm{BBB}, 4=\mathrm{A}, 5=\mathrm{AA}$. The accuracy of the in-sample forecast is shown at the bottom of the table, where the percent correctly predicted is reported. The standard errors are in parentheses. The variables are defined as follows. LOGASSETS Log of asset size of borrowers, SIC2-8 Industry dummies, EA Equity to assets ratio, ROA Return on assets, STDEBTRATIO Short-term to total debts ratio, YR2-6 Year dummies, QUICK Quick ratio.

\begin{tabular}{|c|c|}
\hline Independent Variables & Probit \\
\hline Intercept 0 & $\begin{array}{l}5.0295 \text { *** } \\
(0.7609)\end{array}$ \\
\hline Intercept 1 & $\begin{array}{l}7.1075 \text { *** } \\
(0.7684)\end{array}$ \\
\hline Intercept 2 & $\begin{array}{l}8.2341 \text { *** } \\
(0.7777)\end{array}$ \\
\hline Intercept 3 & $\begin{array}{l}9.1391 \text { *** } \\
(0.7908)\end{array}$ \\
\hline Intercept 4 & $\begin{array}{l}10.2952 \text { *** } \\
(0.8363)\end{array}$ \\
\hline LOGASSETS & $\begin{array}{l}-0.3679 \text { *** } \\
(0.0378)\end{array}$ \\
\hline SIC2 & $\begin{array}{r}0.0196 \\
(0.1626)\end{array}$ \\
\hline SIC3 & $\begin{array}{l}0.2614 * \\
(0.1430)\end{array}$ \\
\hline SIC4 & $\begin{array}{l}-0.1271 \\
(0.1255)\end{array}$ \\
\hline SIC5 & $\begin{array}{r}0.1920 \\
(0.1806)\end{array}$ \\
\hline SIC6 & $\begin{array}{l}-0.5706 * * \\
(0.2462)\end{array}$ \\
\hline SIC7 & $\begin{array}{r}0.0484 \\
(0.1489)\end{array}$ \\
\hline SIC8 & $\begin{array}{c}0.437 \text { ** } \\
(0.1812)\end{array}$ \\
\hline EA & $\begin{array}{l}-0.5467 \text { *** } \\
(0.1425)\end{array}$ \\
\hline $\mathrm{ROA}$ & $\begin{array}{l}-1.9552 \text { *** } \\
(0.3222)\end{array}$ \\
\hline STDEBTRATIO & $\begin{array}{l}-0.4232 \text { ** } \\
(0.2110)\end{array}$ \\
\hline QUICK & $\begin{array}{l}0.1851 \text { *** } \\
(0.0362)\end{array}$ \\
\hline YR2 & $\begin{array}{l}0.2687 \text { ** } \\
(0.1344)\end{array}$ \\
\hline YR3 & $\begin{array}{r}0.1598 \\
(0.1336)\end{array}$ \\
\hline YR4 & $\begin{array}{c}0.4263 \text { *** } \\
(0.1391)\end{array}$ \\
\hline YR5 & $\begin{array}{l}0.3607 \text { ** } \\
(0.1451)\end{array}$ \\
\hline YR6 & $\begin{array}{l}0.2763 * \\
(0.1421)\end{array}$ \\
\hline Number of Observations & 832 \\
\hline Ln Likelihood Fn & -918.35 \\
\hline$\%$ correctly predicted & 0.518 \\
\hline$\%$ correctly predicted within $+/$ - rating level & 0.923 \\
\hline
\end{tabular}


Table VI

The Effects of Fleet and BankBoston Merger on All-in-Spread for

Loans Made to Borrowers Inside and Outside of New England

The dependent variable in all regressions is the all-in-spread of the loan in basis points. The table reports the results from standard OLS and the second-step regressions of the two-step regression corrected for endogenous binary variable BBF, which indicates whether the lead lender of the loan is Fleet/BankBoston or not. The firststep Probit regressions of the two-step regressions are reported in Table VIII. The construction of the sample and summary statistics of the sample are discussed in Table II. The standard errors are reported in parentheses below the coefficient estimates. The independent variables are defined as follows. BBF Indicator variable equals one if BankBoston or Fleet is the lead lender as identified by LPC or is the sole lender for the deal or holds the leading role in syndication with the following titles:administrative, syndication, documentation agent, SMALL Indicator variable for borrower with sales less than $\$ 100$ millions, MEDIUM Indicator variable for borrower with sales between $\$ 100-\$ 250$ millions, POST Indicator variable for observations form post-merger period, LOGAMT Log of loan amount, LOGSALES Log of borrower sales, EA Equity over assets,

MATURITY log of number of days to maturity of loan, WORKINGCAP Indicator if loan is for working capital purpose, RPAYDEBT Indicator if loan is for repaying old debt, ACQUISITION Indicator if loan is acquisition related, SOLELEND Indicator if loan is granted by sole lender, TERM Indicator if loan is term loan, STREVOLVER Indicator is loan is revolver with less than 1 year maturity, SECURED Indicator if loan is secured, PRIME Indicator if loan spread is quoted as spread over prime rate, RATEFORECAST Indicator if the rating information used is a forecast. AA,A,BBB,BB,B,CCC Senior bond rating dummies, SIC1-7 and YR2-YR 6 are industry and year dummies which are included but not shown.

\begin{tabular}{|c|c|c|c|c|}
\hline \multirow[b]{2}{*}{ Independent Variables } & \multicolumn{2}{|c|}{ New England } & \multicolumn{2}{|c|}{ Outside New England } \\
\hline & OLS & Two-step & OLS & Two-step \\
\hline \multirow[t]{2}{*}{ Intercept } & $654.6440 * * *$ & $660.5070^{* * *}$ & $553.3540 * * *$ & $536.9370^{* * *}$ \\
\hline & $(143.2240)$ & $(137.3940)$ & $(56.3258)$ & $(56.9429)$ \\
\hline \multirow[t]{2}{*}{$\mathrm{BBF}$} & 17.4008 & 16.7448 & 7.0693 & $28.2560 * *$ \\
\hline & $(27.6816)$ & $(45.8866)$ & $(19.2880)$ & $(33.5203)$ \\
\hline \multirow[t]{2}{*}{ BBF*SMALL } & $-67.6184 * *$ & $-67.5228 * *$ & 2.2409 & -3.7699 \\
\hline & $(30.9595)$ & $(29.2157)$ & $(22.4707)$ & $(21.4748)$ \\
\hline \multirow[t]{2}{*}{ BBF*MEDIUM } & $-99.2542 * * *$ & $-101.241 * * *$ & 20.2123 & 19.7457 \\
\hline & $(30.5689)$ & $(29.1183)$ & $(23.2370)$ & $(21.9857)$ \\
\hline \multirow[t]{2}{*}{ POST } & 10.3263 & 8.5937 & $36.9497 * * *$ & $36.4636 * * *$ \\
\hline & $(16.7367)$ & $(17.2931)$ & $(4.9122)$ & $(4.9650)$ \\
\hline \multirow[t]{2}{*}{ POST*BBF } & -18.3195 & -18.4874 & -12.0872 & -8.2445 \\
\hline & $(32.6274)$ & $(30.7931)$ & $(25.8359)$ & $(24.5075)$ \\
\hline \multirow[t]{2}{*}{ POST*BBF*SMALL } & -15.8149 & -15.8862 & 3.5393 & 1.4070 \\
\hline & $(38.9662)$ & $(36.7683)$ & $(31.9457)$ & $(30.2176)$ \\
\hline \multirow[t]{2}{*}{ POST*BBF*MEDIUM } & $112.4257 * * *$ & $113.2306 * * *$ & -4.9994 & -7.6720 \\
\hline & $(20.1448)$ & $(28.0170)$ & $(33.1700)$ & (31.3429) \\
\hline \multirow[t]{2}{*}{ LOGAMT } & $-21.5229 * * *$ & $-20.8524 * * *$ & -1.2950 & -0.4576 \\
\hline & $(4.6707)$ & $(5.1789)$ & $(1.4990)$ & $(1.5485)$ \\
\hline \multirow[t]{2}{*}{ LOGSALES } & $-12.1076 *$ & $-13.0520 *$ & $-12.7754 * * *$ & $-12.2131 * * *$ \\
\hline & $(6.6501)$ & $(7.3506)$ & $(1.9517)$ & $(1.9811)$ \\
\hline \multirow[t]{2}{*}{ EA } & $-55.7401 * * *$ & $-59.1264 * * *$ & $-62.6881 * * *$ & $-62.6413 * * *$ \\
\hline & $(16.9553)$ & $(21.0667)$ & $(5.2013)$ & $(5.2570)$ \\
\hline \multirow[t]{2}{*}{ MATURITY } & 11.6657 & 11.3688 & $-11.1172 * * *$ & $-12.4372 * * *$ \\
\hline & $(8.4914)$ & $(8.1153)$ & $(2.6490)$ & $(2.7248)$ \\
\hline \multirow[t]{2}{*}{ WORKINGCAP } & $26.9168 * *$ & $26.0007 * *$ & 7.0371 & $7.8336 *$ \\
\hline & $(12.8180)$ & $(12.6683)$ & $(4.5457)$ & $(4.6044)$ \\
\hline \multirow[t]{2}{*}{ RPAYDEBT } & $26.5881 * *$ & $24.3605 *$ & 1.8166 & -1.1423 \\
\hline & (12.3192) & $(14.7133)$ & $(3.6686)$ & $(3.8770)$ \\
\hline ACQUISITION & $35.6878 * * *$ & 35.3715 *** & $19.0224 * * *$ & $19.0144 * * *$ \\
\hline & $(13.6480)$ & $(12.9637)$ & $(4.3306)$ & $(4.3765)$ \\
\hline SOLELEND & 11.9944 & 10.4071 & 1.4232 & 1.9980 \\
\hline & $(14.2130)$ & $(14.8843)$ & $(4.6211)$ & $(4.6752)$ \\
\hline TERM & 11.7088 & 13.0963 & $33.9741 * * *$ & $34.5937 * * *$ \\
\hline & $(10.9769)$ & (11.7917) & $(3.4676)$ & $(3.5130)$ \\
\hline STREVOLVER & -26.0821 & -27.3298 & $-27.1439 * * *$ & $-27.3063 * * *$ \\
\hline & $(18.4498)$ & $(18.1517)$ & $(5.9289)$ & $(5.9931)$ \\
\hline SECURED & $48.7052 * * *$ & $49.6778 * * *$ & $59.6468 * * *$ & $57.3096 * * *$ \\
\hline & $(13.6204)$ & $(13.4605)$ & $(4.6957)$ & (4.8301) \\
\hline PRIME & $134.2580 * * *$ & $136.1690 * * *$ & $122.6130 * * *$ & $126.9960 * * *$ \\
\hline & $(14.1490)$ & $(15.4399)$ & $(4.6091)$ & $(4.9517)$ \\
\hline RATEFORECAST & -15.1513 & -14.3195 & $-25.7124 * * *$ & $-26.9872 * * *$ \\
\hline & $(25.3886)$ & $(24.2299)$ & $(9.0166)$ & $(9.1236)$ \\
\hline $\mathrm{AA}$ & & & $-123.8360 * *$ & $-124.2540 * *$ \\
\hline & & & $(52.7209)$ & $(52.0305)$ \\
\hline A & -48.2209 & -47.5203 & $-141.4760 * * *$ & $-141.1490 * * *$ \\
\hline & $(77.4241)$ & (73.1453) & $(39.2606)$ & $(39.2570)$ \\
\hline BBB & 26.1023 & 28.4252 & $-109.4880 * * *$ & $-107.1330 * * *$ \\
\hline & (59.7049) & $(57.1679)$ & $(37.9121)$ & $(37.8886)$ \\
\hline BB & -12.2005 & -9.8005 & -43.2243 & -41.2940 \\
\hline & $(56.9161)$ & $(54.6274)$ & (37.4793) & (37.4494) \\
\hline B & 12.7113 & 12.8552 & -26.1027 & -24.1697 \\
\hline & $(54.8110)$ & (51.7791) & $(37.3638)$ & (37.3321) \\
\hline CCC & & & -4.0177 & -2.7456 \\
\hline & & & $(38.3472)$ & $(38.3342)$ \\
\hline Inverse Mills Ratio & & -5.6919 & & $-36.3837 * * *$ \\
\hline & & $(22.9790)$ & & $(13.9099)$ \\
\hline Number of Observations & 330 & 330 & 4218 & 4218 \\
\hline Adjusted -R sq & 0.524 & 0.438 & 0.522 & 0.444 \\
\hline
\end{tabular}

***,**,* denote significant difference at $1 \%, 5 \%$, and $10 \%$ level, respectively. 
Table VII

Combined Regressions Measuring the Effects of Fleet and BankBoston Merger on

All-in-Spread for All Loan Made in the U.S.

The dependent variable is the all-in-spread of the loan in basis points. The table reports the regression for the combined observations both inside and outside of New England. The independent variables are the same as in Table VI with an additional variable, NE, which equals one for New England borrowers. Standard errors are in the parentheses. The second-step regressions of the two-step regressions are corrected for the endogenous binary variable BBF, which indicates whether the lead lender of the loan is Fleet/BankBoston or not. The first-step Probit regressions of the two-step regressions are reported in Table VIII. The year dummies and industry dummies are included but not shown.

\begin{tabular}{|c|c|c|c|}
\hline \multirow[b]{2}{*}{ Independent Variables } & \multicolumn{3}{|c|}{ All loans } \\
\hline & OLS & Two-step & \\
\hline \multirow[t]{2}{*}{ Intercept } & $561.3430 * * *$ & 550.0080 & *** \\
\hline & $(54.8707)$ & $(55.2448)$ & \\
\hline \multirow[t]{2}{*}{$\mathrm{NE}$} & -4.3665 & -14.7203 & \\
\hline & $(8.5394)$ & $(10.3969)$ & \\
\hline \multirow[t]{2}{*}{$\mathrm{BBF}$} & 8.7442 & 56.3787 & $*$ \\
\hline & $(19.1245)$ & $(33.2345)$ & \\
\hline \multirow[t]{2}{*}{$\mathrm{BBF}^{*} \mathrm{NE}$} & 33.4121 & 23.3982 & \\
\hline & $(36.5884)$ & $(36.2691)$ & \\
\hline \multirow[t]{2}{*}{$\mathrm{BBF} * \mathrm{SMALL}$} & -0.4210 & -2.2518 & \\
\hline & $(22.2751)$ & $(21.7668)$ & \\
\hline \multirow[t]{2}{*}{$\mathrm{BBF} * \mathrm{SMALL} * \mathrm{NE}$} & $-52.1825 *$ & -50.8425 & $*$ \\
\hline & $(25.3982)$ & $(26.5158)$ & \\
\hline \multirow[t]{2}{*}{ BBF*MEDIUM } & 18.7045 & 18.6504 & \\
\hline & $(23.0482)$ & $(22.4663)$ & \\
\hline BBF*MEDIUM*NE & $-102.2356 * * *$ & -103.9821 & $* * *$ \\
\hline & $(42.6967)$ & $(41.7555)$ & \\
\hline POST & $36.1350 * * *$ & 35.3897 & $* * *$ \\
\hline & $(4.7649)$ & $(4.7949)$ & \\
\hline POST*NE & -8.0949 & -7.5230 & \\
\hline & $(12.7907)$ & $(12.7410)$ & \\
\hline POST*BBF & -12.6900 & -10.0181 & \\
\hline & $(25.6327)$ & $(25.0424)$ & \\
\hline $\mathrm{POST}^{*} * \mathrm{BBF} * \mathrm{NE}$ & -14.8599 & -16.5458 & \\
\hline & $(46.3339)$ & $(45.3392)$ & \\
\hline POST*BBF*SMALL & 3.1079 & 0.5391 & \\
\hline & $(31.6939)$ & $(30.9186)$ & \\
\hline POST*BBF*SMALL*NE & -18.5856 & -18.6971 & \\
\hline & $(55.5981)$ & $(54.3549)$ & \\
\hline POST*BBF*MEDIUM & -5.0988 & -6.6600 & \\
\hline & $(32.9114)$ & $(32.0715)$ & \\
\hline POST*BBF*MEDIUM*NE & $128.0280 * * *$ & 130.8221 & $* * *$ \\
\hline & $(57.6230)$ & $(56.3241)$ & \\
\hline LOGAMT & $-2.6202 *$ & -1.9009 & \\
\hline & $(1.4325)$ & $(1.4949)$ & \\
\hline LOGSALES & $-12.6536 * * *$ & -12.4825 & $* * *$ \\
\hline & $(1.8749)$ & $(1.8805)$ & \\
\hline EA & $-61.1864 * * *$ & -62.0513 & $* * *$ \\
\hline & $(4.9788)$ & $(5.0164)$ & \\
\hline MATURITY & $-9.4924 * * *$ & -10.3287 & $* * *$ \\
\hline & $(2.5452)$ & $(2.5970)$ & \\
\hline WORKINGCAP & $8.0910 *$ & 8.1606 & $*$ \\
\hline & $(4.3104)$ & $(4.3215)$ & \\
\hline RPAYDEBT & 2.8997 & 0.4404 & \\
\hline & $(3.5296)$ & $(3.8123)$ & \\
\hline ACQUISITION & $19.7704 * * *$ & 19.6653 & $* * *$ \\
\hline & $(4.1553)$ & $(4.1664)$ & \\
\hline SOLELEND & 1.8685 & 1.8877 & \\
\hline & $(4.4198)$ & $(4.4307)$ & \\
\hline TERM & $32.4864 * * *$ & 33.1765 & $* * *$ \\
\hline & $(3.3262)$ & $(3.3585)$ & \\
\hline STREVOLVER & $-26.8137 * * *$ & -27.1286 & $* * *$ \\
\hline & $(5.6735)$ & $(5.6912)$ & \\
\hline SECURED & $58.3519 * * *$ & 57.2873 & $* * *$ \\
\hline & $(4.4677)$ & $(4.5212)$ & \\
\hline PRIME & $122.1900 * * *$ & 125.5130 & $* * *$ \\
\hline & $(4.4061)$ & $(4.8152)$ & \\
\hline RATEFORECAST & $-23.3316 * * *$ & -23.2279 & $* * *$ \\
\hline & $(8.4210)$ & $(8.4419)$ & \\
\hline $\mathrm{AA}$ & $-122.4270 * *$ & -122.5510 & $* *$ \\
\hline & $(52.3111)$ & $(51.8858)$ & \\
\hline A & $-141.3830 * * *$ & -140.2440 & $* * *$ \\
\hline & $(38.8659)$ & $(38.7819)$ & \\
\hline BBB & $-103.0160 * * *$ & -100.8720 & $* * *$ \\
\hline & $(37.5656)$ & $(37.4863)$ & \\
\hline BB & -45.9963 & -43.9576 & \\
\hline & $(37.1750)$ & $(37.0937)$ & \\
\hline B & -27.8672 & -26.3943 & \\
\hline & $(37.0708)$ & $(36.9802)$ & \\
\hline $\mathrm{CCC}$ & -4.6880 & -3.9451 & \\
\hline & $(38.0327)$ & $(37.9426)$ & \\
\hline Inverse Mills Ratio & & -23.6930 & $*$ \\
\hline & & $(13.6570)$ & \\
\hline Number of Observations & 4548 & 4548 & \\
\hline Adjusted - R sq & 0.438 & 0.438 & \\
\hline
\end{tabular}


Table VIII

First-Step Probit Regressions Predicting Firm Borrowing from FleetBoston

The table reports probit regressions predicting BBF - an indicator variable for whether the loan is made by Fleet or BankBoston. The predicted probability for $\mathrm{BBF}=1$ is then used to construct inverse Mills ratio for second-step regressions reported in Tables VI and VII. The variables are defined as in Tables II and VI with additional variables defined as follows. LDIST log of distance in miles between borrower headquarters and FleetBoston headquarters, LDIST2 the square of log of distance in miles between borrower headquarters and FleetBoston headquarters, LATITUDE Latitude coordinate of borrower headquarters, LONGITUDE negative Longitude coordinate of borrower headquarters. Industry and year dummies are included but not shown.

\begin{tabular}{|c|c|c|c|}
\hline Independent V ariables & All loans & New England & Outside NE \\
\hline Intercept & -0.5063 & $-35.8903^{* *}$ & $\begin{array}{l}18.9836^{* * *} \\
(5.9507)\end{array}$ \\
\hline \multirow{2}{*}{ LDIST } & $0.6565 * * *$ & $0.4744 * *$ & 0.3776 *** \\
\hline & $(0.1860)$ & $(0.1883)$ & $(0.0546)$ \\
\hline \multirow[t]{2}{*}{ LDIST2 } & $-0.1115 * * *$ & $-0.0979 * * *$ & $-0.1172 * *$ \\
\hline & $(0.0237)$ & $(0.0248)$ & $(0.0479)$ \\
\hline LATITUDE & $-0.0405 * * *$ & -0.2165 & $-0.0076 * *$ \\
\hline \multirow[t]{2}{*}{ LONGITUDE } & $-0.0293 * * *$ & -0.1759 & $-0.0303 * *$ \\
\hline & $(0.0078)$ & $(0.1595)$ & $(0.0125)$ \\
\hline NE & $\begin{array}{l}0.6467 \text { *** } \\
(0.1803)\end{array}$ & & \\
\hline \multirow{2}{*}{ POST } & 0.6260 & -19.4890 & -5.4463 \\
\hline & $(1.0293)$ & $(44.4815)$ & $(8.5259)$ \\
\hline \multirow[t]{2}{*}{ POST*NE } & 0.0867 & & \\
\hline & $(0.2825)$ & & \\
\hline \multirow[t]{2}{*}{ POST*LDIST } & -0.3937 & -0.2733 & 1.4447 \\
\hline & $(0.2598)$ & $(0.5740)$ & $(2.6798)$ \\
\hline \multirow[t]{2}{*}{ POST*LDIST2 } & $0.0663 *$ & 0.0174 & -0.0925 \\
\hline & $(0.0349)$ & $(0.1264)$ & $(0.2401)$ \\
\hline \multirow[t]{2}{*}{ POST*LATITUDE } & $0.0351 *$ & -0.1863 & 0.0284 \\
\hline & $(0.0198)$ & $(0.2771)$ & $(0.0292)$ \\
\hline \multirow[t]{2}{*}{ POST*LONGITUDE } & $0.0240 *$ & -0.4000 & 0.0112 \\
\hline & $(0.0125)$ & $(0.5389)$ & $(0.0279)$ \\
\hline \multirow[t]{2}{*}{ LOGAMT } & $-0.1294 * * *$ & $-0.2831 * * *$ & $-0.1091 * * *$ \\
\hline & $(0.0326)$ & $(0.1007)$ & $(0.0360)$ \\
\hline \multirow[t]{2}{*}{ LOGSALES } & -0.0356 & 0.14223 & -0.0779 \\
\hline & $(0.0425)$ & $(0.1278)$ & $(0.0474)$ \\
\hline \multirow[t]{2}{*}{ EA } & $0.1976 *$ & $1.4232 * * *$ & 0.0777 \\
\hline & $(0.1172)$ & $(0.4338)$ & $(0.1263)$ \\
\hline \multirow[t]{2}{*}{ MATURITY } & $0.1504 * *$ & 0.2038 & $0.1860 * *$ \\
\hline & $(0.0650)$ & $(0.1798)$ & $(0.0738)$ \\
\hline \multirow[t]{2}{*}{ WORKINGCAP } & 0.0140 & 0.2594 & -0.1774 \\
\hline & $(0.1048)$ & $(0.2568)$ & $(0.1264)$ \\
\hline RPAYDEBT & $0.4190 * * *$ & $0.8729 * * *$ & $0.3516 * * *$ \\
\hline & $(0.0827)$ & $(0.2423)$ & $(0.0900)$ \\
\hline ACQUISITION & 0.0236 & 0.0552 & -0.0496 \\
\hline & $(0.1015)$ & $(0.2908)$ & $(0.1116)$ \\
\hline SOLELEND & -0.0207 & $0.5701 * *$ & -0.1137 \\
\hline & $(0.1018)$ & $(0.2698)$ & $(0.1181)$ \\
\hline TERM & $-0.1263 *$ & $-0.5596 * *$ & -0.0829 \\
\hline & $(0.0760)$ & $(0.2266)$ & $(0.0826)$ \\
\hline STREVOLVER & 0.0486 & 0.6004 & -0.0853 \\
\hline & $(0.1483)$ & $(0.3801)$ & $(0.1814)$ \\
\hline SECURED & $0.2230 * *$ & -0.4042 & $0.4007 * * *$ \\
\hline & $(0.1113)$ & $(0.2762)$ & $(0.1391)$ \\
\hline PRIME & $-0.7026 * * *$ & $-0.6620 * *$ & $-0.7714 * * *$ \\
\hline & $(0.1182)$ & $(0.2762)$ & $(0.1431)$ \\
\hline RATEFORECAST & 0.1601 & -0.6520 & 0.3052 \\
\hline & $(0.1884)$ & $(0.5570)$ & $(0.2050)$ \\
\hline A & -0.3784 & & -0.2746 \\
\hline & $(0.5712)$ & & $(0.5818)$ \\
\hline BBB & -0.5493 & -0.8248 & -0.4609 \\
\hline & $(0.5342)$ & $(0.8416)$ & $(0.5449)$ \\
\hline BB & -0.5299 & -0.5085 & -0.4326 \\
\hline & $(0.5228)$ & $(0.8306)$ & $(0.5308)$ \\
\hline B & -0.4564 & 0.3391 & -0.4493 \\
\hline & $(0.5189)$ & $(0.8144)$ & $(0.5259)$ \\
\hline $\mathrm{CCC}$ & -0.3977 & & -0.3948 \\
\hline & $(0.5616)$ & & $(0.5723)$ \\
\hline $\bar{N}$ & 4548 & 330 & 4218 \\
\hline Pseudo-R sq & 0.0960 & 0.2820 & 0.0534 \\
\hline
\end{tabular}


Table IX

The Mean Difference in All-in-spread between BBF loans and Matched Non-BBF Loans

The table shows estimates of mean difference between the all-in-spread of BBF and non-BBF loans broken down by borrower sales and location. To control for multiple loan characteristics, we follow the econometric matching method suggested by Heckman, Ichimura, and Todd $(1997,1998)$ by constructing the propensity score of being a BBF loan through the probit model shown in Table VIII. The results for estimators using different kernels, such as nearest neighbors, Gaussian, and Epanechnikov are similar. Only the results from the Gaussian kernel are shown below. The top numbers are the mean difference between BBF loans and non-BBF loans, where negative numbers indicate that BBF loans all-in-spread are at discount to non-BBF loans on average. The standard error estimates for testing the mean difference from zero are shown in parentheses with $* * *, * *, *$ denoting significance at the $1 \%, 5 \%$, and $10 \%$ level, respectively.

\begin{tabular}{|c|c|c|c|}
\hline & Size & New England & Non-New England \\
\hline \multirow{3}{*}{ 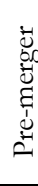 } & Small & $\begin{array}{c}-56.16^{* * *} \\
(13.22)\end{array}$ & $\begin{array}{c}-8.52 \\
(16.26)\end{array}$ \\
\hline & Medium & $\begin{array}{c}-94.52^{* * *} \\
(18.21)\end{array}$ & $\begin{array}{c}19.00 \\
(19.55)\end{array}$ \\
\hline & Large & $\begin{array}{c}62.63 \\
(46.88)\end{array}$ & $\begin{array}{c}16.97 \\
(28.39)\end{array}$ \\
\hline \multirow{3}{*}{ 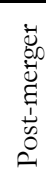 } & Small & $\begin{array}{c}-89.03^{* * *} \\
(18.27)\end{array}$ & $\begin{array}{l}-28.40 \\
(24.58)\end{array}$ \\
\hline & Medium & $\begin{array}{l}-17.78 \\
(26.05)\end{array}$ & $\begin{array}{l}-17.54 \\
(16.82)\end{array}$ \\
\hline & Large & $\begin{array}{c}13.43 \\
(16.61)\end{array}$ & $\begin{array}{c}3.57 \\
(23.77)\end{array}$ \\
\hline
\end{tabular}




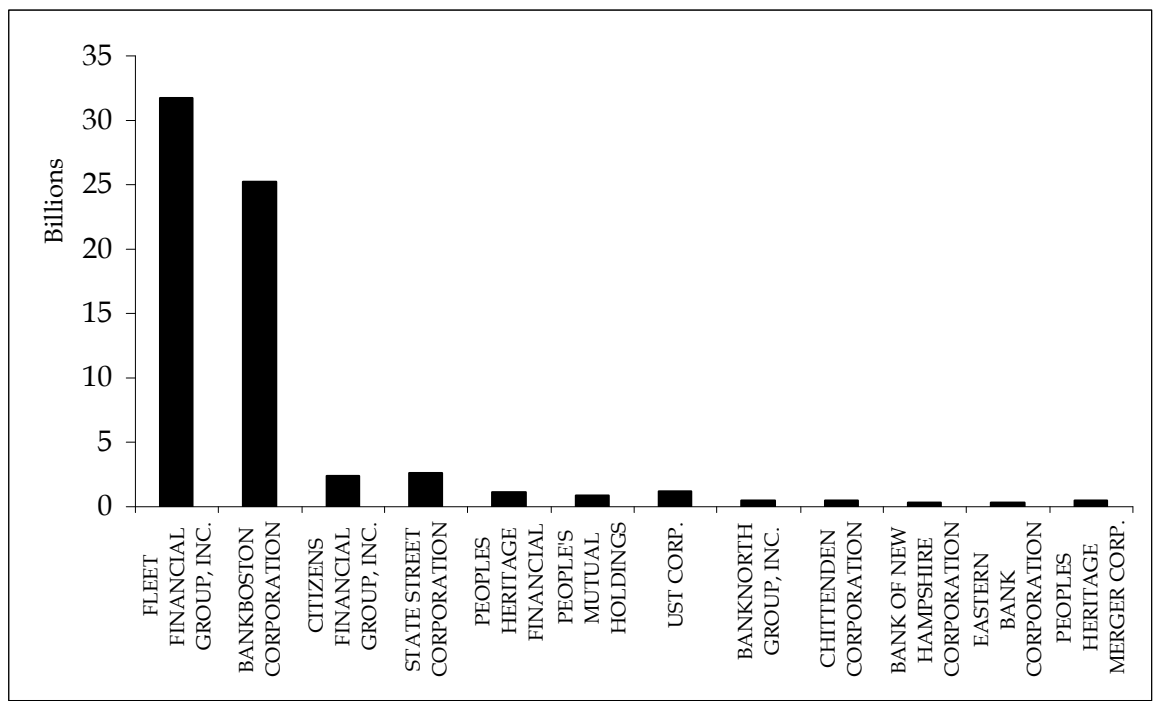

Figure II

\section{Fleet and BankBoston Loan Pricing Functions}

\section{Loan Spread}

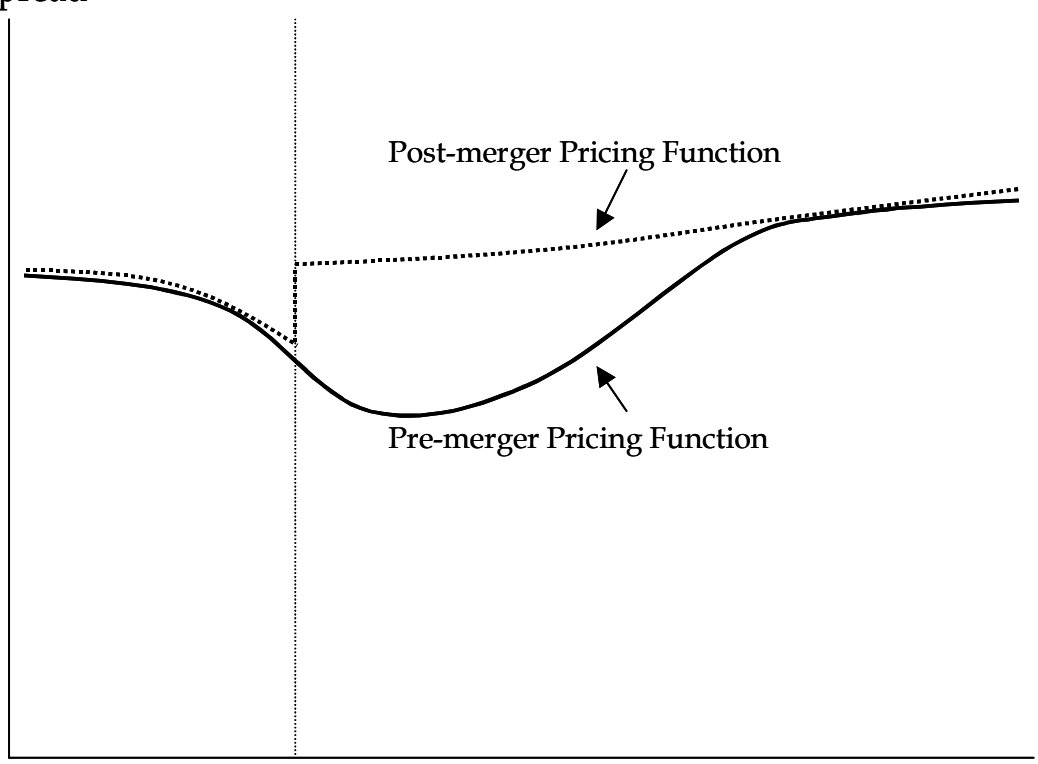

Maximum Loan-to-One Borrower Limit for Competing Small Banks

Middle-Market

Borrower Size 